\title{
Field phenotyping of plant roots by electrical capacitance - a standardized methodological protocol for application in plant breeding: a Review**
}

\author{
Tomáš Středa ${ }^{1 *}$, Jan Haberle ${ }^{2}$, Jana Klimešová ${ }^{1}$, Agnieszka Klimek-Kopyra ${ }^{3}$, Hana Středová ${ }^{4}$, \\ Gernot Bodner ${ }^{5}$, and Oldřich Chloupek ${ }^{1}$ \\ ${ }^{1}$ Department of Crop Science, Breeding and Plant Medicine, Mendel University in Brno, Czech Republic \\ ${ }^{2}$ Division of Crop Management Systems, Crop Research Institute, Czech Republic \\ ${ }^{3}$ Institute of Plant Production, University of Agriculture in Kraków, Poland \\ ${ }^{4}$ Department of Applied and Landscape Ecology, Mendel University in Brno, Czech Republic \\ ${ }^{5}$ Division of Agronomy, University of Natural Resources and Life Sciences, Austria
}

Received November 16, 2019; accepted January 29, 2020

\begin{abstract}
Due to the absence of a suitable method and standardized procedures, the root systems of plants have been evaluated to a much lesser extent than aboveground organs. The aim of this article is (i) to provide a detailed description and thus standardization of an upgraded procedure of electrical capacitance measurement for evaluating the size of the root system of plants in situ, which allows for a reassessment to be made during the growing season and subsequent harvest of seeds for the planting of selected progenies, (ii) to demonstrate, through a standardized methodological protocol, the applicability of root electrical capacitance measurement as a field phenotyping method for the selection of superior root systems to improve crop abiotic stress tolerance and resource efficiency, (iii) to suggest a standardized methodological protocol for the application of electrical capacitance measurements in breeding nurseries, and (iv) to discuss the methodological aspects, development and limitations of this method. A methodological overview of the use of electrical capacitance to measure plant root systems, which emerged from working groups directed by the author of this unique method, is presented along with a standardized protocol. An overview of the application of electrical capacitance measurements of roots in breeding is shown along with some examples of successful applications.
\end{abstract}

Keyw ords: root system, drought tolerance, varieties, yield

*Corresponding author e-mail: streda@mendelu.cz

**This work was funded by projects No. QK1920224 (20192021) and QK1720285 (2017-2019) of the National Agency for Agricultural Research (NAZV).

\section{INTRODUCTION}

The impact of most agricultural interventions (fertilization, irrigation, tillage) on crop growth and yield is mediated via the plant root system. Despite the essential role of the root system in determining attainable yields, roots have been historically overlooked as the hidden half of plants (Manske and Vlek, 2002; Waisel et al., 1991) and rarely targeted by agricultural crop improvements. With a higher frequency of drought in the context of climate change, and considering that water limitation is a major yield-limiting factor that is increasingly prevalent in temperate regions, plant breeding efforts have started to search for approaches that integrate the root system into the stress tolerance portfolio for trait-based crop improvement. There are several lines of evidence, which show that targeting the root system in the breeding process is highly promising for improving yield stability and crop performance in stress inducing environments. Some biologists, physiologists and breeders involved in plant root research consider the root system to be the key to a second green revolution, which does not rely on expensive inputs (e.g., Gewin, 2010).

(C) 2020 Institute of Agrophysics, Polish Academy of Sciences 


\section{Root systems for crop improvement - which trait to select for?}

The measurement of root characteristics is made difficult by the environment in which the roots develop. In fact, the size of the roots has not been used as a criterion for selection in practical breeding efforts (with the exception of root crops - sugar beet, carrot, etc.), although every new selection criterion initially shows a prompt response to selection as a rule. A rare practical outcome of this was the cultivation of wheat with reduced hydraulic conductivity of the vessels of the root system xylem in Australia's arid climate (Richards and Passioura, 1989).

An important question is which characteristics should be selected by breeders to obtain drought-tolerant plants. Selecting a suitable variety (based on the root system properties) for a specific area may be the key to a grower's success. For example, deep-rooted varieties may be successful in dry years in soils with a higher water table. Gregory et al. (1978) found that only 3\% of the total wheat root biomass occurred at a depth of $1 \mathrm{~m}$, and this small portion provided up to $20 \%$ of the water needed for transpiration during the summer months. Kirkegaard et al. (2007) reported an increase in the grain yield of wheat by $59 \mathrm{~kg}$ $\mathrm{ha}^{-1}$ per $1 \mathrm{~mm}$ of water delivered to a layer of 1.35-1.85 m during drought stress after flowering. Additionally, the topology of the root system, e.g., the different branching angles of the seminal roots in wheat (Manschadi, 2006), is related to the water uptake efficiency.

A larger root system is considered to be an advantage, especially in the absence of sufficient water and nutrients, in a less fertile environment and in organic farming (Comas et al., 2013; Svačina et al., 2014), for enabling a more effective use of the nutrients from the soil, and thus lowering the contamination of the environment with unused nutrients, especially nitrogen and phosphorus (Gewin, 2010; KlimekKopyra and Rębilas, 2018). However, a higher root density did not always lead to an increase in nitrogen consumption (Wendling et al., 2016; Feng et al., 2016; Herrera et al., 2010). When comparing old and modern wheat varieties, Aziz et al. (2017) discovered that the root length density and total length of the root system decreased with ongoing breeding processes, but the efficiency of nitrogen uptake increased. Genotypes with superior root characteristics for efficient nutrient uptake should be developed in breeding programmes to increase grain yield and to minimize nitrate leaching (Ehdaie et al., 2010; Robinson et al., 2018), and appropriate phenotypes must be precisely identified for intentional breeding. Despite improvements in molecular technologies, fast and accurate phenotyping remains the major bottleneck to enhancing yield gains in water-limited environments (Richards et al., 2010).

However, the shallow topsoil profiles of stony soils are inappropriate for deep-rooted varieties. Blum (2005) considers plants with a deep reaching extensive root system to be ill suited for conditions of rapid drying of the upper layer of the soil, which (by its mechanical properties) prevents the pronounced proliferation of roots. Growth is then curtailed, so that the genetic potential for long roots remains unused.

In contrast, Richards (1991) stated that, for some environments, the formation of fewer roots in the upper soil layer may be an effective adaptation to drought. This could be related to the conclusions of Campos et al. (2004), who investigated the water obtained by the root system of old and modern varieties of maize. The old varieties showed a higher depletion of water predominantly from the upper parts of the soil profile. In particular, the depletion of water in the soil prior to the beginning of flowering was the reason for a more pronounced decline in the yield of older varieties compared to that of modern hybrids. The "Green Revolution" resulted in dwarf varieties of wheat capable of responding to higher fertilizer inputs, but they failed to reach resource-poor farmers. Crossing early green revolution wheat varieties, with an $\mathrm{F}_{2}$ of Norin 10 or Brevor, reduced root biomass. Later generation, semi-dwarf wheat showed a genetic variation in root biomass, but some generations exhibited a further reduction in root size (Waines and Ehdaie, 2007). From this point of view, the optimal regionalization of varieties with a larger root system is essential.

Optimally, it is also desirable to take into account the root system morphology of a particular variety (the depth of the root system) or the dynamics of root growth during vegetative growth. Significant correlations between the root system size of barley in the stage of stem elongation during moderate drought stress and the seed vigour of progenies were found by Vintrlíková et al. (2015). It is likely that the increase in the root system of parents during drought stress conditions has enabled the rapid growth of the roots of progenies at the beginning of the vegetation period. However, a large sized root system is not always a great advantage. For example, if drought does not occur, then the development of a larger root system was an unnecessary investment for the plant at the expense of other photosynthetic products. The precise targeting of a variety to a particular area of cultivation may serve as the basis for the success and economic prosperity of farmers.

For an improved exploitation of the available water, an adequate distribution of roots in the soil profile is preferable to a higher dry matter content of the roots (Bänziger et al., 2000). In cereals, root densities of $1.0-1.5 \mathrm{~cm} \mathrm{~cm}^{-3}$ are required for the plant to extract the available water from the soil (Passioura, 1980; Vamerali et al., 2003). Lynch (2013) characterized the maize ideotype for its optimal uptake of water and mobile nutrients as steep, cheap and deep. This promotes the phenotypic or genotypic selection of a larger (deeper) root system in cereals.

Fitter (2002) reported that high values of SRL (specific root length; root length per root weight unit) indicates the high ability of the roots to obtain nutrients. Similarly, Gonzalez-Dugo (2010) reported that the availability of 
nitrogen is largely determined by root density. Palta et al. (2011) demonstrated significantly higher nitrogen and water absorption in wheat lines with a more vital root system at a depth of up to $0.7 \mathrm{~m}$. Herrera et al. (2010) described the importance of the fast growth of the roots in deep soil layers at the beginning of the vegetation period, which may lower nitrogen losses through leaching. The fast growth of the root system of field crops is vital in order to prevent nitrates from leaching to deeper layers of the soil profile, however, the role of the root system in nitrogen uptake efficiency is still a point of controversy (Palta and Watt, 2009). A larger investment by a crop in fine roots that are deeper in the soil and fewer roots in surface layers would improve yields by allowing plants to access additional resources (King et al., 2003). Bertholdsson and Kolodinska Brantestam (2009) showed the importance of early vigour for drought tolerance and the development of finer roots in modern barley cultivars.

It may be concluded that there is a large variation in root system characteristics and the functional strategies of plants within a given species. This is, on the one hand, a positive finding (varietal selection for superior root system traits is possible). On the other hand, it is necessary to factor in varietal differences in the creation and interpretation of experiments. Being critical to the integrity of the plant, the root system parameters affect the efficiency of the whole plant. Roots are very sensitive to soil conditions and are often the first organ of a plant that responds to stress. The adaptability of the root system confirms the excellent ability of roots to change their morphological properties to achieve the optimal growth of the whole plant.

With a degree of generalization, it may be stated that deep-rooted varieties can be recommended in areas with a high water retention capacity in the subsoil. Varieties with a large, shallow root system may be recommended in drier areas with regular, lower amounts of precipitation, during which only the upper layer of the soil profile is moistened (Tron et al., 2015).

\section{The field phenotyping gap}

An ideal method for evaluating root systems should allow the researcher to obtain a detailed characterization of a wide range of root system parameters with a sufficiently large number of measurements. Unfortunately, a universal, inexpensive, reliable and rapid method combining the measurement of the morphological, physiological, quantitative and qualitative properties of root systems in field experiments is not known. A method for the isolation of intact living root systems from soil in fields has not yet been published and would seem to be impossible. For example, biomass estimates from minirhizotrons indicate that the $<0.25 \mathrm{~mm}$ diameter roots account for nearly $95 \%$ of the total root length (Brown et al., 2009).

In general, several basic groups of methods are widely applied for root system evaluation: (i) in situ excavation methods (destructive methods - measurements on the same plant cannot be repeated; time-consuming and laborious); evaluation is carried out directly at the site of plant growth, (ii) soil block methods (ex situ methods, removal of soil blocks of different sizes from the soil profile; time-consuming and laborious; destructive methods - measurements on the same plant cannot be repeated; allowing the evaluation of the morphological parameters of the root system), the evaluation of the samples takes place in the laboratory, (iii) imaging methods (in situ methods such as computed tomography (CT), magnetic resonance imaging (MRI), etc.), (iv) electrical methods - methods of measuring electrical capacitance/impedance (in situ methods, specified in more detail below); (v) root windows, rhizobox, minirhizotron and rhizotron methods, i.e., in situ methods, different-sized glass or plastic containers for plant growth, specifically designed for root system research (Böhm, 1979; Smit et al., 2000).

In situ methods are ideal for assessing plant root system properties. In situ imaging techniques (CT, MRI) provide a detailed and relatively accurate determination of the size and architecture of the root system. These methods are not affected by error in the form of quantitative losses of root biomass but are limited by the high cost of the measuring devices. These methods also do not allow the evaluation of a large number of plants, and their use under field conditions is unrealistic.

\section{METHODOLOGY}

\section{Methodological developments, modifications and criticisms of root system electrical capacitance measurement}

Another variant of in situ measurements, based on measuring the electrical characteristics of the root system, can be used in both laboratory and field conditions when measuring an intact root system. The experience of the authors with this in situ method shows that the measurement of root system size by electrical capacitance is ideal for plant species with a root system that is only slightly suberized - for example, the root systems of cereals or some vegetables. Monocots became less suberized than dicots. It should be noted that lignin and suberin deposition is also a natural process in ageing root systems. Ageing roots show a decrease in both electrical capacitance and impedance (Cseresnyés et al., 2013a).

For cereals, a high correlation value is achieved between the root's electrical capacitance and the weight of the root system (Cseresnyés et al., 2018). The probability of the successful selection of a larger root system according to the electrical capacitance is high. In recent years, the size of the root system (measured by electrical capacitance) has been used as a criterion for the selection of genotypes that are tolerant to drought, such as those of spring barley (Chloupek et al., 2010; Svačina et al., 2014) and winter wheat (Heřmanská et al., 2015). It was verified that varieties of wheat and barley with a larger root system size 
provided higher yields and contained more assimilates (more starch in wheat and barley and more glycid extract in barley) and less nitrogenous substances than those varieties with a smaller root system. This is similar to irrigation in dry conditions (Paynter and Young, 2004). In the experiments of Středa et al. (2012), in a dry year, the varieties of wheat that showed the greatest difference in root system size were found to exhibit a yield difference of $860 \mathrm{~kg} \mathrm{ha}^{-1}$, which translates approximately to the use of an additional $15 \mathrm{~mm}$ of subsoil water. However, in some places (in years with above average amounts of precipitation or in wet localities), there was a negative relationship between the size of the root system and the yield. Spring barley requires $293 \mathrm{~mm}$ of soil water during its vegetation period (Martyniak, 2008). On the basis of the results of PeltonenSainio et al. (2011) spring cereal yields decreased by up to $75 \mathrm{~kg} \mathrm{ha}^{-1}$ due to a decrease in precipitation by $10 \mathrm{~mm}$, and according to the results of Chloupek et al. (2010), the 9.5\% varietal root system size differences in the case of barley, the increment of the higher root system size to water depletion accounts for 40 out of $293 \mathrm{~mm}$, i.e. for about $14 \%$ of the total demand.

\section{Method description}

A prospective in situ method with the potential to save money, labour and time is measuring the size of the root system by its electrical capacitance as a part of the electrical impedance. This unique method was originally published by Chloupek (1972) and has been intensively developed at the Mendel University in Brno, Czech Republic (Chloupek et al., 2010; Středa et al., 2012; Středa and Chloupek, 2013; Svačina et al., 2014; Herrmanská et al., 2015) in the last decade. The method is applicable under field conditions and allows the detection of fine structures in the root system. Another field method for the repeated comparative evaluation of the same individual plants at different stages of development with the subsequent possibility of harvesting seeds from the selected plants is not known. The direct link between root system size and yield is an important precondition for successful and practical breeding based on root system properties. However, the influence of soil conditions on the measured results and the inability to directly capture the morphological characteristics of the root system could be disadvantages of this method.

The relationships between the value of the root's electrical capacitance and weight, length, surface or volume of the root system have been demonstrated and published many times (e.g., Rajkai et al., 2005). It has been established that derivation of root system morphology on the basis of electrical capacitance values is not possible (Dietrich et al., 2013). However, the main advantage of this method is the ability to measure hundreds of plants a day and repeat the measurements at different phenological stages. In addition, the measurements are not adversely affected by the roots of neighbouring plants. This is ideal for making a comparison between genotypes and individuals and for selection during breeding under field conditions.

\section{Theory}

Plant tissue acts as a capacitor when electric current passes through it, this tissue has an electrical capacitance (Cseresnyés et al., 2019; Postic and Doussan, 2016). The magnitude of this electrical capacitance can be measured in physical units - micro- and nanofarads. At the contact surface of two substances that differ in their dielectric constants, a thin double-electric layer develops, and an electric field is formed. The capacitor plates in this case are the root surfaces and the soil environment. The larger the relative area of the capacitor plates, the smaller their mutual distance, the higher the permittivity of the dielectric between the plates, and the greater the electrical capacitance. The permittivity of cellulose increases with water content and this depends on the frequency at which the electrical capacitance is measured. The approximate value of the electrical capacitance for biological membranes is $0.9 \mu \mathrm{F} \mathrm{cm}^{-2}$ (Montal and Mueller, 1972). This uniform, specific electrical capacitance of biological membranes per unit area inspired Chloupek (1972) to evaluate the relationship between the size of root systems and their electrical capacitance. The closest correlation between electrical capacitance and root system size was experimentally found at a measuring frequency of $1 \mathrm{kHz}$ (Chloupek, 1977). For this reason, the frequency of $1 \mathrm{kHz}$ is most frequently used when measuring the electrical capacitance of root systems. The measured capacitance reflects not only the root system size but also membrane vitality because dying membranes lose their electrical capacitance. The root system shows a high degree of functional activity mainly in the lateral roots. There is an association between the size of the measured electrical capacitance and the developmental stage of plants. Their capacitance increases to its maximum at a certain developmental phase of the plant and then decreases. This is caused by a decrease in the effective area of the roots (suberization of cell walls, necrosis of part of the root biomass), which is able to draw an electric charge. At the same time, there is a relationship between the thickness of cell walls and capacitance. Suberization of cell walls increases their diameter and moves the capacitor plates away from each other; therefore, the measured capacitance becomes smaller. The other reason for the decrease in electrical capacitance is that lignin and suberin have a lower permittivity than the other main component materials of the root. The variability in their quantity causes a considerable variation in the dielectric properties of the root tissue (Cseresnyés et al., 2017). A root system with young active roots therefore has a greater capacitance. An indisputable advantage of the method is that, as a result of biophysical principles, it has the ability to measure even the finest root structures (root hairs). 


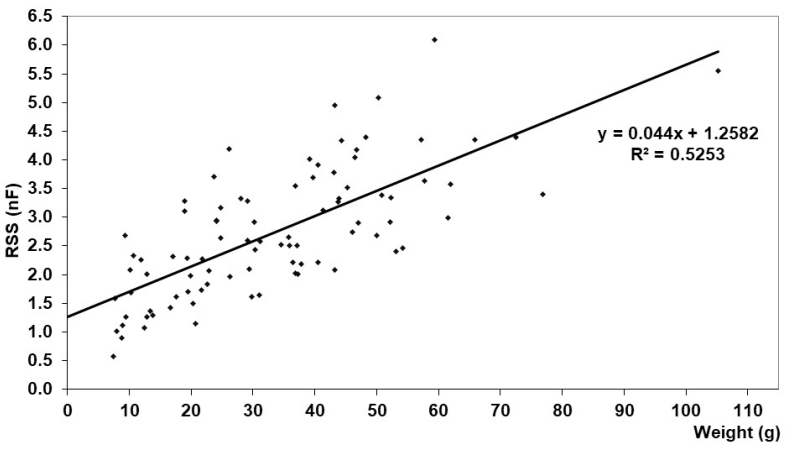

Fig. 1. Relationship between electric capacitance and the weight of the main roots of 92 carrot plants (Chloupek et al., 2010).

A simple verification of the relationship between the root system size and the electric capacitance with carrot roots was conducted in the experiment of Chloupek et al. (2010). The results showed a significant correlation ( $\mathrm{p}<$ 0.001 ) between electric capacitance and root weight and root volume, even if the main root was evaluated without lateral rootlets, which contribute substantially to the total surface area of the root. The correlation between electric capacitance and the fresh weight and volume of the roots amounted to $\mathrm{r}^{2}$ value of $0.394-0.525$ and $0.388-0.501$, respectively, as shown in Fig. 1.

\section{Root system electrical capacitance - a standardized methodological protocol}

Based on the long-term experience of the authors with the study method, correct results and meaningful interpretation are only possible if standardized measurement principles are followed:

1. A comparison between capacitance values can only be made for measurements on plants of the same species (e.g., Triticum aestivum). It is not possible to compare differences between species or within a family (i.e., differences such as Triticum aestivum versus Hordeum vulgare). Different varieties of the same species may be compared if they are morphologically similar (e.g., number of tillers).

2. When measuring the electrical capacitance of the root system, the plants should be in approximately the same growth phase on the day of measurement, a margin of a fewdays difference in the earliness of varieties does not pose a problem. The root system grows more intensively in the vegetative growth phase. Differences in earliness are more critical in the vegetative growth phase.

3 . The surface of the measured plant stem must not be wet (drops of water from dew or rain) so that the measuring current does not pass to neighbouring plants in the stand.

4. The soil surface must not be wet (i.e., immediately following rain or with ponding on the soil surface) but it may be moist.
5. It is not possible to compare the differences between plants growing in different substrates. This means that it is only possible to compare plants within one plot thereby keeping soil conditions similar (e.g., the same is true for irrigation). The heterogeneity of the soil conditions between experimental plots must be eliminated by a sufficient number of replicates (plant measurements from more experimental plots or at different sites on the plot). It is not possible to compare the values of root system electrical capacitance from fields far from each other with different soil, agrochemical and soil-climatic conditions. With increasing soil moisture, the electrical capacitance increases. Similarly, soil chemistry (content of ions in the soil) has an effect on the values of electrical capacitance. Nevertheless, some recent studies concerning this topic have proved that soil ion content has a marginal effect on the capacitance-root mass regression.

6. In the case of pot experiment evaluations, it is only possible to compare values from pots with the same substrate (e.g., sand) and the same watering and nutrient addition regimes. Therefore, it is not possible to compare values from variants from, for example, drought stress or fertilizer treatments. Similarly, when assessing the data of the electrical capacitance of roots from hydroponic experiments, a comparison between different concentrations of solutions or solutions of different chemical compositions could produce misleading results.

7. Comparable measurements should be taken on the same day (preferably within a window of several hours) to avoid any dramatic changes in soil conditions, e.g., rainfall, topsoil drying on hot days.

8. An important measurement choice is the relevant growth stage when determining the electrical capacitance of the root system, especially when evaluating yield or production quality. Wang et al. (2014) showed that maximum values of root system weight occur in wheat during the flowering stage. With respect to the climatic conditions of central Europe, we propose that the root system should be evaluated during the shooting, heading and grain maturity stages, which are periods when nutrient requirements are at their highest because of the rapid increase in biomass, i.e., for cereals, approximately $\mathrm{BBCH} 36(\mathrm{BBCH}$ according to Meier, 1997), BBCH 55 and BBCH 71-73.

9. The distance between electrodes (the electrode in the soil and the electrode located on the plant) has an effect on the measured electrical capacitance. When positioning the soil electrode, it is always important to maintain the same distance from the stem electrode (stem). The ideal distance is $5-10 \mathrm{~cm}$.

10. The position of the stem electrode (distance from the soil surface) must be constant. With increasing distance from the roots, resistance increases and capacitance decreases. When attaching the electrode, it is therefore necessary to keep the distance from the roots as small as possible (Dalton, 1995). 
11. It is ideal practice to establish plant stands at regular intervals (e.g., cereals $0.125 \times 0.03 \mathrm{~m}$ ). This arrangement is implemented for convenience and to prevent damage to the adjacent plants. Nevertheless, performing measurements in normal stands (sown at normal stand density) is also possible and the method has been verified. However, in the case of repeated measurements, it is necessary to distinguish (mark) the measured plants from the others.

12. The materials used for measuring the size of a root system via electrical capacitance (Středa and Chloupek, 2013) consist of a digital LCR multimeter, commonly used, e.g., for measuring the capacitance of capacitors. The LCR multimeter is connected to an electrically conductive electrode (soil electrode) and electrically conductive pliers (stem electrode) (Fig. 2). Alternatively, a needle may be used as the stem electrode instead of pliers (e.g., for measuring Beta vulgaris, Brassica napus var. napus, etc.). The LCR multimeter parameter settings are as follows: $1 \mathrm{kHz}$ frequency of measurement, parallel capacitance (Cp), measurements in $\mathrm{nF}$ (nanofarads). In general, the measured values range from several tenths to nanofarad units. Commercial instruments such as the universal LCR multimeter can be used for these measurements.

13. The construction of the electrodes influences the electrical capacitance values of the roots (Kormanek et al., 2016). In order to evaluate the differences within a single measurement, only the values from one set of electrodes need to be used to perform the root system measurements.

14. One electrode (metal pliers for cereals, alfalfa, etc.) or needle (for sunflower, corn, oilseed rape, carrot, sugar beet, etc.) must be placed on the plant stem base $(1-5 \mathrm{~cm}$ above the ground without touching the soil surface). In the case of cereals, it is necessary to grasp (by pliers) the tillers as well because they are not always conductively connected. The other electrode (soil electrode) must be inserted into the soil to a depth of approximately $10 \mathrm{~cm}$, always at the same depth and at the same distance from the measured plant. A deeper placement of the ground electrode increases the measured capacitance of the root system due to the larger contact surface between the electrode and the soil.

15. It is always necessary to measure the electrical capacitance of at least dozens of individual plants (to ensure the sufficiently stable value of the results when comparing varieties). The minimum number of measured individual plants depends on the variability of the soil conditions, the variability of the plot surface and the biological characteristics of the species (uniformity). The degree of variability should be determined by preparatory measurements prior to the start of the main measurements. For cereals from standard small-scale experiments, the minimum number of plants for measurement is 30 per line (at least the number of measuring sites in the canopy multiplied by 10 plants). Repeated evaluations increase the accuracy of the method.
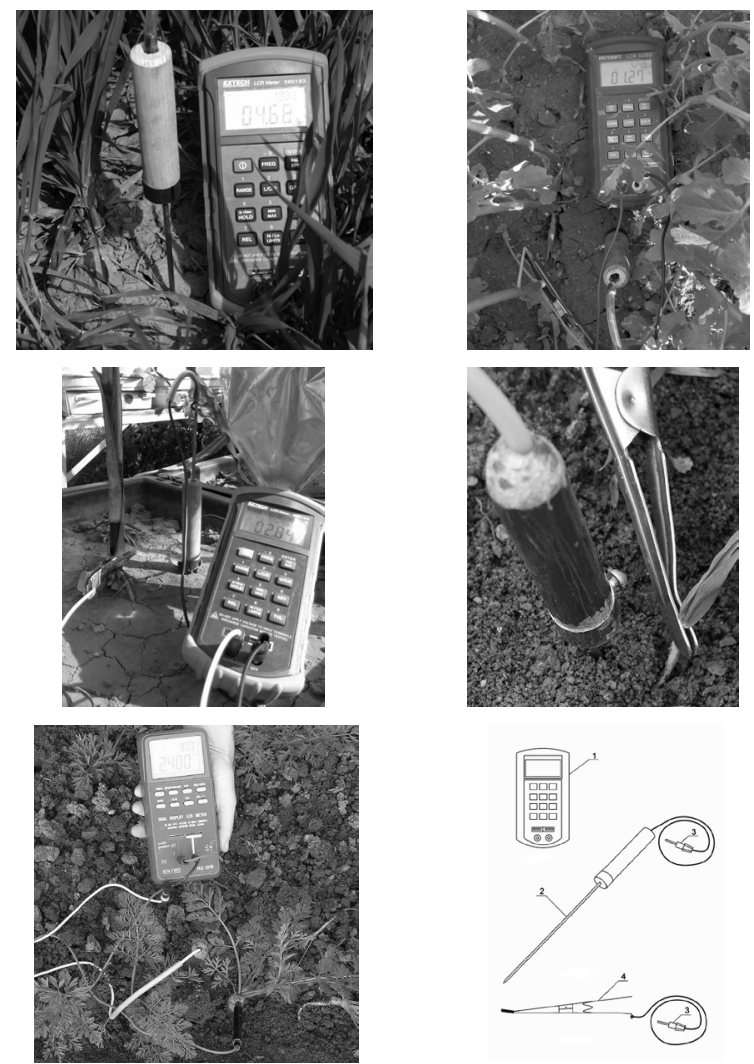

Fig. 2. Measuring the electrical capacitance of different crop root system variants with pliers (wheat, mustard, maize, wheat in detail) and with a stem needle (carrot); the schematic of the materials used for measuring root system size via electrical capacitance: a digital LCR multimeter (1), soil electrode (2), connector (3), stem electrode (4).

Obviously, with an increasing number of measured plants (more replications, more measured individuals per replication), the impact of experimental error decreases.

16. Differences between genotypes can be evaluated (i) separately between individual measurement periods (there are differences in the root biomass growth rate between genotypes) or (ii) with the average values for all the measurements (the average value represents the size of the genotype root system over a longer vegetation phase).

\section{DISCUSSION}

\section{Applications of electrical capacitance in plant breeding}

Under dry conditions, the size of the root system was related to grain yield, it showed a response to selection. Spring barley plants with a root system increase of $3.9 \%$ exhibited a yield increase of $8.1 \%$ in our previous experiment (Svačina et al., 2014) (Fig. 3).

Similarly, in our experiment (Heřmanská et al., 2015), six varieties of winter wheat were mutually crossed, and eighteen populations were sown in the field. For plants of the third and fourth generation $\left(\mathrm{F}_{3}\right.$ and $\left.\mathrm{F}_{4}\right)$ and their parents, the size of the root system was assessed by measuring its electrical capacitance. The plants with the largest root 


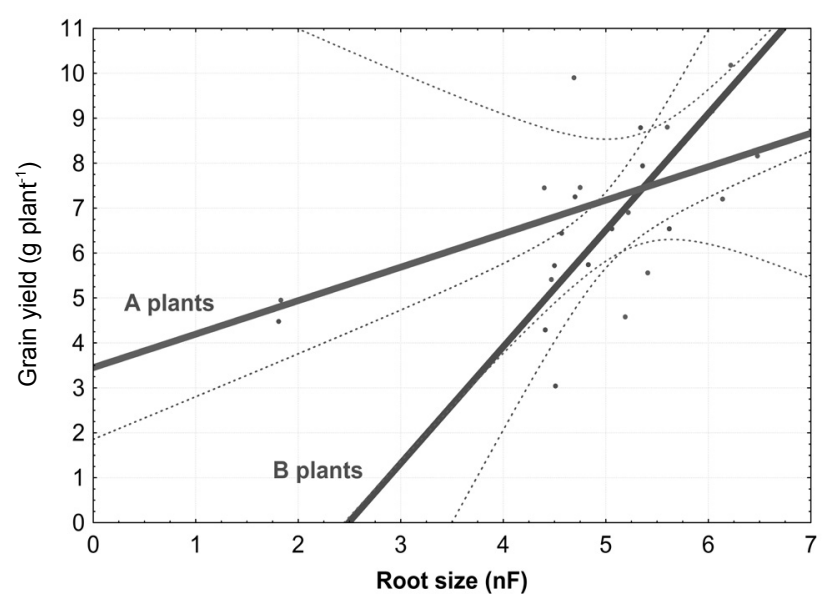

Fig. 3. Relationship between root system size and grain yield in selection A (largest roots) and selection B (smallest roots) plants. Scatterplot with regression lines and 95\% confidence bands (Svačina et al., 2014).

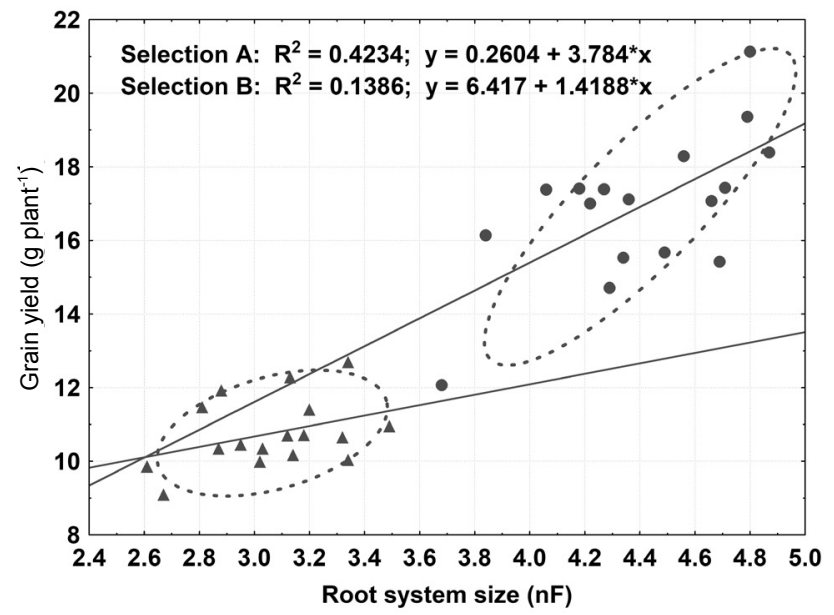

Fig. 4. Relationship between the root system size and the yield of winter wheat grains $\left(\mathrm{F}_{3}\right.$ generation, dry year, average of three locations, the plot is shown with $95 \%$ confidence ellipses - the confidence ellipses show where a specified percentage of the data in a scatter plot will lie).

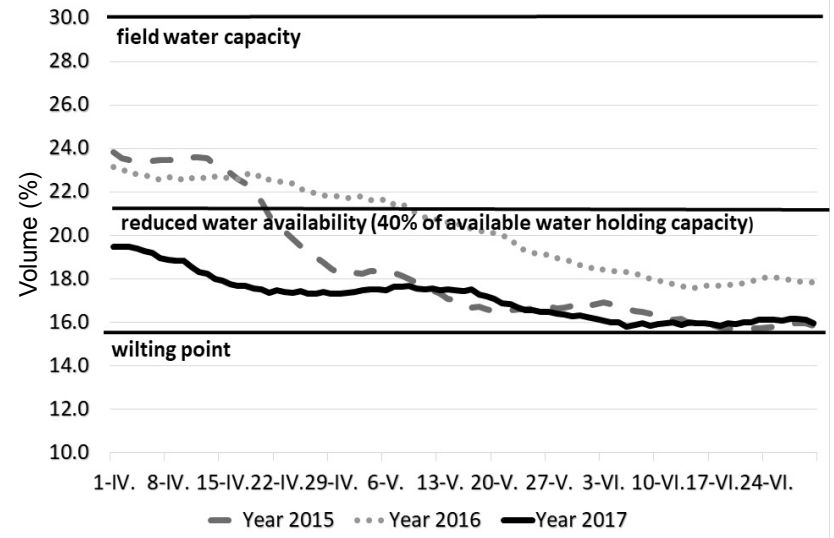

Fig. 5. Volume of soil moisture measured by VIRRIB sensors at a depth of $30 \mathrm{~cm}$ (Branišovice, 2015-2017). system (selection A) and with the smallest (selection B) root system were selected. Grains from plants of groups $\mathrm{A}$ and $\mathrm{B}$ were sown in the next generation. The size of the root system was evaluated in relation to the grain yield in a given generation. The relationship between the size of roots and the grain yield was significant $(\mathrm{p}<0.01)$ for selection $\mathrm{A}$ $\left(r^{2}=0.423\right.$, Fig. 4 upper line) but not for selection $B\left(r^{2}=\right.$ 0.139 , Fig. 4 bottom line). Thus, selection for a larger root system could increase the yield of grain, extract and starch of cereals during dry years and in naturally drier localities.

The aim of our current research (Šmardová et al., 2018) was to evaluate the relationship between the root system size as measured by electrical capacitance in three phenological stages and the wheat grain yield. The root system size and winter wheat grain yield were evaluated in a field experiment at the dry locality of Branišovice (Fig. 5) in the Czech Republic in the years 2015-2017.

The correlation analysis of the relationships between the root system size and grain yield was particularly significant in 2015 (Table 1). Early genotypes created a larger root system at the time of root system size measurement, which was subsequently reflected by an increase in grain yield. Early varieties with rapid initial development, growth, premature flowering, and an overall shorter growing season are able to complete their development and to mature at a time before drought produces a significantly negative impact on grain yields (Blum and Naveh, 1976).

Table 1. Relationship between RSS and grain yield of winter wheat expressed by correlation coefficient

\begin{tabular}{|c|c|c|c|c|}
\hline \multirow[b]{2}{*}{ Genotypes } & \multirow{2}{*}{$\begin{array}{c}\text { Stem } \\
\text { elongation }\end{array}$} & \multicolumn{2}{|c|}{ Stage } & \multirow[b]{2}{*}{ Average } \\
\hline & & Heading & $\begin{array}{l}\text { Grain } \\
\text { filling }\end{array}$ & \\
\hline \multicolumn{5}{|c|}{2015} \\
\hline All $(n=39)$ & $0.414 * *$ & 0.161 & 0.159 & $0.394 *$ \\
\hline Late $(\mathrm{n}=11)$ & 0.350 & 0.362 & 0.029 & 0.454 \\
\hline Early $(n=26)$ & $0.494 *$ & 0.028 & 0.109 & $0.417 *$ \\
\hline \multicolumn{5}{|c|}{2016} \\
\hline All $(n=14)$ & 0.378 & 0.513 & -0.052 & 0.487 \\
\hline Late $(n=5)$ & -0.622 & 0.181 & -0.581 & -0.555 \\
\hline Early $(\mathrm{n}=9)$ & 0.452 & 0.579 & 0.066 & 0.661 \\
\hline \multicolumn{5}{|c|}{$2015+2016$} \\
\hline All $(n=14)$ & 0.472 & $0.603 *$ & 0.362 & $0.581^{*}$ \\
\hline Late $(n=5)$ & -0.801 & 0.747 & 0.047 & -0.685 \\
\hline Early $(n=9)$ & 0.663 & 0.439 & 0.413 & $0.784 *$ \\
\hline \multicolumn{5}{|c|}{2017} \\
\hline All $(n=6)$ & -0.293 & -0.516 & -0.283 & -0.367 \\
\hline
\end{tabular}

All - early and late genotypes, late - late genotypes, early - early genotypes; statistically significant values of correlation coefficient level of: ${ }^{*} p \leq 0.05,{ }^{* *} p \leq 0.01$. 
Table 2. Examples of practical use of electrical capacitance for root system parameters by other authors

\begin{tabular}{|c|c|c|c|c|}
\hline Year & Author & Plant species & $\begin{array}{l}\text { Experiment } \\
\text { type }\end{array}$ & EC correlated (especially) with \\
\hline 1982 & Kendall & Red clover, Alfalfa & PE, FE & root dry weight; $\mathrm{r}^{2}=0.76$ \\
\hline 1995 & Dalton & Tomato & PE & root dry weight; $\mathrm{r}^{2}=0.77$ \\
\hline 1998 & van Beem et al. & Maize & FE, PE & root fresh mass; $\mathrm{r}^{2}=0.56-0.73$ \\
\hline 2000 & Psarras and Merwin & Apple & PE & root dry weight; $\mathrm{r}^{2}=0.73$ \\
\hline 2004 & Preston et al. & Poplar hybrids & PE, FE & $\begin{array}{l}\text { root dry mass, root fresh mass; } \\
r^{2}=0.78-0.89\end{array}$ \\
\hline 2005 & $\begin{array}{l}\text { Ozier-Lafontaine and } \\
\text { Bajazet }\end{array}$ & Tomato, Amaranthus & $\mathrm{PE}, \mathrm{H}$ & $\begin{array}{l}\text { fresh and dry weight of roots; } \\
\mathrm{r}^{2}=0.94-0.99\end{array}$ \\
\hline 2005 & Rajkai et al. & Sunflower & $\mathrm{PE}$ & $\begin{array}{l}\text { root fresh mass, root length; } \\
r^{2}=0.53-0.92\end{array}$ \\
\hline 2005 & Repo et al. & Willow & $\mathrm{H}$ & root volume \\
\hline 2006 & Čermák et al. & 6 woody species & $\mathrm{FE}$ & $\begin{array}{l}\text { stem basal area, crown projected } \\
\text { area; } r^{2}=0.88\end{array}$ \\
\hline 2006 & Monneveux et al. & Maize & $\mathrm{FE}$ & \\
\hline 2008 & McBride et al. & Maize & $\mathrm{H}$ & \\
\hline 2009 & Tsukahara et al. & Peach, Japanese pear & $\mathrm{FE}$ & $\begin{array}{l}\text { root dry mass, fresh mass, root } \\
\text { dry mass; } r^{2}=0.81-0.89\end{array}$ \\
\hline 2009 & Vamerali et al. & Poplar (several species), Willow & $\mathrm{PE}$ & root weight; $\mathrm{r}^{2}=0.28$ \\
\hline 2010 & Cao et al. & Willow & $\mathrm{H}$ & $\begin{array}{l}\text { root surface area, number or } \\
\text { laterals; } r=0.93 \text { and }-0.91\end{array}$ \\
\hline 2010 & Pitre et al. & Willow (hybrids) & PE & $\begin{array}{l}\text { root dry weight, root biomass; } \\
r^{2}=0.66-0.81\end{array}$ \\
\hline 2011 & Messmer et al. & Maize & $\mathrm{FE}$ & \\
\hline 2012 & Aulen and Shipley & 10 crop and forage species & PE & root dry mass; $r^{2}=0.30$ \\
\hline 2012 & Dietrich et al. & Barley & $\mathrm{H}$ & $\begin{array}{l}\text { fresh mass, cross-sectional area of } \\
\text { nodal and seminal roots; } \\
r^{2}=0.77-0.87\end{array}$ \\
\hline 2012 & Worku et al. & Maize & $\mathrm{FE}$ & \\
\hline 2013 & Cseresnyés et al. & Maize & $\mathrm{PE}$ & $\begin{array}{l}\text { root dry biomass, root surface } \\
\text { area; } r^{2}=0.92-0.95\end{array}$ \\
\hline 2013 & Cseresnyés et al. & Maize & $\mathrm{PE}$ & $\begin{array}{l}\text { root dry mass, root surface area, } \\
\text { root length; } \mathrm{r}^{2}=0.89-0.94\end{array}$ \\
\hline 2013 & Dietrich et al. & Wheat, Barley & $\mathrm{PE}, \mathrm{FE}$ & $\begin{array}{l}\text { root dry mass, stem cross-section; } \\
r^{2}=0.75 \text { and } 0.93\end{array}$ \\
\hline 2013 & Ellis et al. & Woody plants (4 species) & FE & $\begin{array}{l}\text { root length, root mass, root } \\
\text { surface area; } r^{2}=0.71-0.99\end{array}$ \\
\hline 2013 & Ellis et al. & Faba bean & PE & $\begin{array}{l}\text { root length, root mass, root } \\
\text { surface area; } r^{2}=0.21-0.31\end{array}$ \\
\hline 2014 & Cseresnyés et al. & Cucumber, Bean & $\mathrm{PE}$ & $\begin{array}{l}\text { daily transpiration; } \mathrm{r}^{2}=0.77 \text { and } \\
0.89\end{array}$ \\
\hline 2014 & Ebrahimi et al. & Wheat (T. durum and $T$. turanicum) & FE & \\
\hline 2014 & Nakhforoosh et al. & Wheat (several species and varieties) & $\mathrm{FE}$ & $\begin{array}{l}\text { root length density; } \\
\mathrm{r}=0.70-0.82\end{array}$ \\
\hline 2014 & Takács et al. & Maize, Cucumber, Bean & $\mathrm{PE}$ & \\
\hline 2015 & Kormanek et al. & European beech & PE & $\begin{array}{l}\text { root length, root area, root dry } \\
\text { weight; } r=0.50-0.82\end{array}$ \\
\hline 2016 & Carlson and Smart & Willow (3 species) and their hybrids & PE & $\begin{array}{l}\text { root dry weight, stem dry weight; } \\
r=0.88 \text { and } 0.72\end{array}$ \\
\hline 2016 & Cseresnyés et al. & Maize, Barnyard grass, Abutilon & $\mathrm{PE}$ & root dry mass; $\mathrm{r}^{2}=0.90-0.96$ \\
\hline 2016 & Cseresnyés et al. & Soybean & $\mathrm{PE}$ & root dry mass; $\mathrm{r}^{2}=0.84-0.94$ \\
\hline 2016 & Postic and Doussan & Wheat (Triticum durum) & PE & root dry mass; $\mathrm{r}^{2}=0.79$ \\
\hline
\end{tabular}


Table 2. Continuation

\begin{tabular}{|c|c|c|c|c|}
\hline Year & Author & Plant species & $\begin{array}{l}\text { Experiment } \\
\text { type }\end{array}$ & EC correlated (especially) with \\
\hline 2016 & Repo et al. & Scots pine & $\mathrm{PE}$ & \\
\hline 2016 & Sabo et al. & Tomato, Bell pepper & PE & \\
\hline 2016 & Sharma and Carena & Maize & $\mathrm{FE}$ & $\begin{array}{l}\text { plant height, days of silking, } \\
\text { number of brace roots; } \\
\mathrm{r}=0.3-0.46\end{array}$ \\
\hline 2016 & Školníková and Škarpa & Maize & $\mathrm{H}$ & root dry matter weight; $r=0.99$ \\
\hline 2016 & $\mathrm{Wu}$ and $\mathrm{Ma}$ & Canola & $\mathrm{FE}$ & $\begin{array}{l}\text { more parameters of roots; } \\
r^{2}=0.32-0.99\end{array}$ \\
\hline 2017 & Wu et al. & Canola & $\mathrm{PE}$ & $\begin{array}{l}\text { more parameters of roots, } \\
\mathrm{r}=0.66-0.92\end{array}$ \\
\hline 2018 & Cseresnyés et al. & Maize, Soybean & PE, FE & root dry mass; $\mathrm{r}^{2}=0.83-0.87$ \\
\hline
\end{tabular}

$\mathrm{PE}$ - pot experiment; FE, field experiment, $\mathrm{H}$ - hydroponics; if there is no value in the "EC correlated (especially) with" column, the study was a comparison of species/varieties, $r$ - coefficient of correlation, $r^{2}=$ coefficient of determination.

From the aforementioned correlation coefficients, it is not always possible to consider a positive relationship between the root system size and the grain yield. In particular, in 2017, the root system did not affect the grain yield; on the contrary, the larger root system had a negative impact on grain yield. In the extraordinarily dry year of 2017 , the bigger roots could probably not have given certain plants an advantage, since there was no water available in the soil. In fact, it was quite the opposite, it was a rather useless waste of assimilates. This is a significant contribution to the discussion concerning the impact of root system size on yield in different environments.

Methods for the evaluation of plant root system parameters through the measurement of their electrical capacitance have been successfully used and published by other authors for various plant species. The literature concerning the application of electrical capacitance was reviewed from the first introduction of this method in 1972. Some examples of the practical use of the method for evaluating monocotyledonous species, including cereals, dicotyledonous plants and woody plants, are shown below (Table 2).

\section{SUMMARY}

Agricultural research and plant breeding are particularly concerned with the results of research carried out under field conditions, which often differ significantly from laboratory experiments or pot trials. The unique method of root system electrical capacitance measurement allows for both the accurate and repeated evaluation as well as the harvesting of selected plants under field conditions. A comprehensive review of root system electrical capacitance in plant breeding research and applications in a diverse range of crops will highlight the important role of this simple field method in the current plant phenotyping landscape.

The method of plant root system evaluation under field conditions described in this study, which is particularly useful for root phenotyping, has been applied both in research and practice many times. Based on the long-term experience of the authors with the method, correct results and meaningful interpretation are only possible if the standardized measurement principles described are followed in full. From the experiences described here, the standardization of the method, including certain mandatory procedures, is proposed. The optimization of the methods, the identification of weak points and the elimination of their negative impacts on the results of the evaluation is thus guaranteed.

Conflict of interest: The Authors do not declare conflict of interest.

\section{REFERENCES}

Aulen M. and Shipley B., 2012. Non-destructive estimation of root mass using electrical capacitance on ten herbaceous species. Plant Soil, 355, 41-49, https://doi.org/10.1007/ s11104-011-1077-3.

Aziz M.M., Palta J.A., Siddique K.H.M., and Sadras V.O., 2017. Five decades of selection for yield reduced root length density and increased nitrogen uptake per unit root length in Australian wheat varieties. Plant Soil, 413, 181192, https://doi.org/10.1007/s11104-016-3059-y.

Bänziger M., Edmeades G.O., Beck D., and Bellon M., 2000. Breeding for drought and nitrogen stress tolerance in maize: From theory to Practice. CIMMYT, Mexico.

Bertholdsson N.-O. and Kolodinska Brantestam A., 2009. A century of Nordic barley breeding - Effects on early vigour root and shoot growth, straw length, harvest index and grain weight. Europ. J. Agronomy, 30, 266-274, https:// doi.org/10.1016/j.eja.2008.12.003.

Blum A., 2005. Drought resistance, water-use efficiency, and yield potential - are they compatible, dissonant, or mutually exclusive? Australian J. Agric. Res., 56, 1159-1168, https://doi.org/10.1071/AR05069.

Blum A. and Naveh M., 1976. Improved water-use efficiency by promoted plant competition in dryland sorghum. Agron. J., 68, 111-116.

Böhm W., 1979. Methods of Studying Root Systems. SpringerVerlag, Berlin, Germany, Heidelberg, New York, USA. 
Brown A.L.P., Day F.P., and Stover D.B., 2009. Fine root biomass estimates from minirhizotron imagery in a shrub ecosystem exposed to elevated $\mathrm{CO}_{2}$. Plant Soil, 317, 145153, https://doi.org/10.1007/s11104-008-9795-x.

Campos H., Cooper M., Habben J.E., Edmeades G.O., and Schussler J.R., 2004. Improving drought tolerance in maize: a view from industry. Field Crops Res., 90, 19-34, https://doi.org/10.1016/j.fcr.2004.07.003.

Cao Y., Repo T., Silvennoinen R., Lehto T., and Pelkonen P., 2010. An appraisal of the electrical resistance method for assessing root surface area. J. Exp. Bot., 61, 2491-2497, doi:10.1093/jxb/erq078.

Carlson C.H. and Smart L.B., 2016. Electrical capacitance as a predictor of root dry weight in shrub willow (Salix; Salicaceae) parents and progeny. Appl. Plant Sci., 4, apps.1600031, https://doi.org/10.3732/apps.1600031.

Chloupek O., 1977. Evaluation of the size of a plants root system using its electrical capacitance. Plant Soil, 48, 525-532, https://doi.org/10.1007/BF02187258.

Chloupek O., 1972. The relationship between electric capacitance and some other parameters of plant roots. Biol. Plantarum, 14, 227-230, https://doi.org/10.1007/BF02921255.

Chloupek O., Dostál V., Středa T., Psota V., and Dvořáčková O., 2010. Drought tolerance of barley varieties in relation to their root system size. Plant Breed., 129, 630-636, https://doi.org/10.1111/j.1439-0523.2010.01801.x.

Comas L.H., Becker S.R., Cruz V.M., Byrne P.F., and Dierig D.A., 2013. Root traits contributing to plant productivity under drought. Front. Plant Sci., 4, 442, https://doi.org/ 10.3389/fpls.2013.00442.

Cseresnyés I., Kabos S., Takács T., Végh K.R., Vozáry E., and Rajkai K., 2017. An improved formula for evaluating electrical capacitance using the dissipation factor. Plant Soil, 419, 237-256, https://doi.org/10.1007/s11104-017-3336-4.

Cseresnyés I., Rajkai K., and Takács T., 2016. Indirect monitoring of root activity in soybean cultivars under contrasting moisture regimes by measuring electrical capacitance. Acta Physiol. Plant., 38, 121, https://doi.org/10.1007/s11738016-2149-z.

Cseresnyés I., Rajkai K., and Vozáry E., 2013a. Role of phase angle measurement in electrical impedance spectroscopy. Int. Agrophys., 27, 377-382, https://doi.org/10.2478/intag2013-0007.

Cseresnyés I., Takács T., Végh K.R., Anton A., and Rajkai K., 2013b. Electrical impedance and capacitance method: A new approach for detection of functional aspects of arbuscular mycorrhizal colonization in maize. Eur. J. Soil Biol., 54, 25-31, https://doi.org/10.1016/j.ejsobi.2012.11.001.

Cseresnyés I., Szitár K., Rajkai K., Füzy A., Mikó P., Kovács R., and Takács T., 2018. Application of electrical capacitance method for prediction of plant root mass and activity in field-grown crops. Front. Plant Sci., 9, 93, https://doi. org/10.3389/fpls.2018.00093.

Cseresnyés I., Takács T., Füzy A., and Rajkai K., 2014. Simultaneous monitoring of electrical capacitance and water uptake activity of plant root system. Int. Agrophys., 28, 537-541, https://doi.org/10.2478/intag-2014-0044.

Cseresnyés I., Takács T., Füzy A., Végh K.R., and Lehoczky E., 2016. Application of electrical capacitance measurement for in situ monitoring of competitive interactions between maize and weed plants. Spanish J. Agric. Res., 14, p. e0904, http://dx.doi.org/10.5424/sjar/2016142-7562.
Cseresnyés I., Takács T., Sepovics B., Kovács R., Füzy A., Parádi I., and Rajkai K., 2019. Electrical characterization of the root system: a noninvasive approach to study plant stress responses. Acta Physiol. Plant., 41, 169, https://doi. org/10.1007/s11738-019-2959-x.

Čermák J., Ulrich R., Stanek Z., Koller J., and Aubrecht L., 2006. Electrical measurement of tree root absorbing surfaces by the earth impedance method: 2 . Verification based on allometric relationships and root severing experiments. Tree Physiol., 26, 1113-1121, https://doi.org/10.1093/ treephys/26.9.1113.

Dalton F.N., 1995. In-situ root extent measurements by electrical capacitance methods. Plant Soil, 173, 157-165, https://doi. org/10.1007/BF00155527.

Dietrich R.C., Bengough A.G., Jones H.G., and White P.J., 2012. A new physical interpretation of plant root capacitance. J. Exp. Bot., 63, 6149-6159, https://doi.org/10.1093/ jxb/ers264.

Dietrich R.C., Bengough A.G., Jones H.G., and White P.J., 2013. Can root electrical capacitance be used to predict root mass in soil? Ann. Bot., 112, 457-464, https://doi.org/10.1093/ aob/met044.

Ebrahimi E., Bodner G., Kaul H.-P., and Nassab A.D.M., 2014. Tetraploid wheat root traits are affected by soil water availability. Book of Abstracts XIIIth Congr. European Society for Agronomy (ESA), August 25-29, Debrecen, Hungary, 433-434.

Ehdaie B., Merhaut D.J., Ahmadian S., Hoops A.C., Khuong T., Layne A.P., and Waines J.G., 2010. Root system size influences water-nutrient uptake and nitrate leaching potential in wheat. J. Agron. Crop Sci., 196, 455-466, https://doi. org/10.1111/j.1439-037X.2010.00433.x.

Ellis T.W., Murray W., Paul K., Kavalieris L., Brophy J., Williams Ch., and Maass M., 2013a. Electrical capacitance as a rapid and non-invasive indicator of root length. Tree Physiol., 33, 3-17, https://doi.org/10.1093/treephys/ tps 115 .

Ellis T., Murray W., and Kavalieris L., 2013b. Electrical capacitance of bean (Vicia faba) root systems was related to tissue density - a test for the Dalton Model. Plant Soil, 366, 575584, https://doi.org/10.1007/s11104-012-1424-Z.

Feng G., Zhang Y., Chen Y., Li Q., Chen F., Gao Q., and Mi G., 2016. Effects of nitrogen application on root length and grain yield of rain-fed maize under different soil types. Agron. J., 108, 1656-1665, https://doi.org/10.2134/ agronj2015.0367.

Fitter A., 2002. Characteristics and functions of root systems. In: Plant roots: The hidden half. Marcel Dekker Inc., New York, USA, 15-32.

Gewin V., 2010. Food: An underground revolution. Nature, 466, 552-553, https://doi.org/10.1038/466552a.

Gonzalez-Dugo V., Durand J.-L., and Gastal F., 2010. Water deficit and nitrogen nutrition of crops. A review. Agron. Sustain. Dev., 30, 529-544, https://doi.org/10.1051/ agro/2009059

Gregory P., McGowan M., and Biscoe P., 1978. Water relations of winter wheat. 2. Soil water relations. J. Agric. Sci., 91, 103-116, https://doi.org/10.1017/S0021859600056665.

Herrera J.M., Feil B., Stamp P., and Liedgens M., 2010. Root growth and nitrate-nitrogen leaching of catch crops following spring wheat. J. Environ. Quality, 39, 845-854, https:// doi.org/10.2134/jeq2009.0306. 
Heřmanská A., Středa T., and Chloupek O., 2015. Improved wheat grain yield by a new method of root selection. Agron. Sustain. Dev., 35, 195-202, https://doi.org/10.1007/ s13593-014-0227-4.

Kendall W.A., Pederson G.A., and Hill R.R., 1982. Root size estimates of red clover and alfalfa based on electrical capacitance and root diameter measurements. Grass Forage Sci., 37, 253-256, https://doi.org/10.1111/j.1365-2494.1982. tb01604.x.

King J., Gay A., Sylvester-Bradley R., Bingham I., Foulkes J., Gregory P., and Robinson D., 2003. Modelling cereal root systems for water and nitrogen capture: towards an economic optimum. Ann. Bot., 91, 383-390, https://doi. org/10.1093/aob/mcg033.

Kirkegaard J.A., Lilley J.M., Howe G.N., and Graham J.M., 2007. Impact of subsoil water use on wheat yield. Australian J. Agric. Res., 58, 303-315, https://doi.org/10.1071/AR06285.

Klimek-Kopyra A. and Rębilas K., 2018. Dependence of pea root mass distribution on weather conditions under varying levels of phosphorus application. Int. Agrophys., 32, 365372, https://doi.org/10.1515/intag-2017-0026.

Kormanek M., Głąb T., and Klimek-Kopyra A., 2016. Modification of the tree root electrical capacitance method under laboratory conditions. Tree Physiol., 36, 121-127, https://doi.org/10.1093/treephys/tpv088.

Lynch J.P., 2013. Steep, cheap and deep: an ideotype to optimize water and $\mathrm{N}$ acquisition by maize root systems. Ann. Bot., 112, 347-357, https://doi.org/10.1093/aob/mes293.

Manschadi A.M., Christopher J., deVoil P., and Hammer G.L., 2006. The role of root architectural traits in adaptation of wheat to water-limited environments. Funct. Plant Biol., 33, 823-837, https://doi.org/10.1071/FP06055.

Manske G.G.B. and Vlek P.L.G., 2002. Root Architecture Wheat as a model plant. In: Plant roots: The hidden half. Marcel Dekker Inc., New York, USA, 249-260.

Martyniak L., 2008. Response of spring cereals to a deficit of atmospheric precipitation in the particular stages of plant growth and development. Agric. Water Manag., 95, 171178, https://doi.org/10.1016/j.agwat.2007.10.014

McBride R., Candido M., and Ferguson J., 2008. Estimating root mass in maize genotypes using the electrical capacitance method. Arch. Agron. Soil Sci., 54, 215-226, https:// doi.org/10.1080/03650340701790658.

Meier U., 1997. BBCH-Monograph. Growth stages of plants Entwicklungsstadien von Pflanzen - Estadios de las plantas - Développement des Plantes. Blackwell Wissenschaftsverlag, Berlin, Wien, Germany, Austria.

Messmer R., Fracheboud Y., Bänziger M., Stamp P., and Ribaut J.-M., 2011. Drought stress and tropical maize: QTLs for leaf greenness, plant senescence, and root capacitance. Field Crops Res., 124, 93-103, https://doi. org/10.1016/j.fcr.2011.06.010.

Monneveux P., Quillérou E., Sanchez C., and Lopez-Cesati J., 2006. Effect of zero tillage and residues conservation on continuous maize cropping in a subtropical environment (Mexico). Plant Soil, 279, 95-105, https://doi.org/10.1007/ s11104-005-0436-3.

Montal M. and Mueller P., 1972. Formation of bimolecular membranes from lipid monolayers and a study of their electrical properties. Proc. National Academy of Sciences of the United States of America, 69, 3561-3566, https://doi. org/10.1073/pnas.69.12.3561.

Nakhforoosh A., Grausgruber H., Kaul H.P., and Bodner G., 2014.
Wheat root diversity and root functional characterization. Plant Soil, 380, 211-229, https://doi.org/10.1007/ s11104-014-2082-0.

Ozier-Lafontaine H. and Bajazet T., 2005. Analysis of root growth by impedance spectroscopy (EIS). Plant Soil, 277, 299-313, https://doi.org/10.1007/s11104-005-7531-3.

Palta J. and Watt M., 2009. Vigorous crop root systems: Form and function for improving the capture of water and nutrients. In: Crop Physiology, Applications for Genetic Improvement and Agronomy. Academic Press, Burlington, Ontario, Canada.

Palta J.A., Chen X., Milroy S.P., Rebetzke G.J., Dreccer M.F., and Watt M., 2011. Large root systems: are they useful in adapting wheat to dry environments? Funct. Plant Biol., 38, 347-354, https://doi.org/10.1071/FP11031.

Passioura J.B., 1980. The transport of water from soil to shoot in wheat seedlings. J. Exp. Bot., 31, 333-345, https://doi. org/10.1093/jxb/31.1.333

Paynter B.H. and Young K.J., 2004. Grain and malting quality in two-row spring barley are influenced by grain filling moisture. Australian J. Agric. Res., 55, 539-550, https://doi. org/10.1071/AR02093.

Peltonen-Sainio P., Jauhiainen L., and Hakala, K., 2011. Crop responses to temperature and precipitation according to long-term multi-location trials at high-latitude conditions. J. Agric. Sci., 149, 49-62, https://doi.org/10.1017/ S0021859610000791.

Pitre F.E., Brereton N.J.B., Audoire S., Richter G.M., Shield I., and Karp A., 2010. Estimating root biomass in Salix viminalis x Salix schwerinii cultivar "Olof" using the electrical capacitance method. Plant Biosyst., 144, 479-483, https:// doi.org/10.1080/11263501003732092.

Postic F. and Doussan C., 2016. Benchmarking electrical methods for rapid estimation of root biomass. Plant Methods, 12, 33, https://doi.org/10.1186/s13007-016-0133-7.

Preston G.M., McBride R.A., Bryan J., and Candido M., 2004. Estimating root mass in young hybrid poplar trees using the electrical capacitance method. Agroforest. Syst., 60, 305309, https://doi.org/10.1023/B:AGFO.0000024439.41932.e2

Psarras G. and Merwin I.A., 2000. Water stress affects rhizosphere respiration rates and root morphology of young „Mutsu“ apple trees on M.9 and MM.111 rootstocks. J. Amer. Soc. Hort.. Sci., 125, 588-595, https://doi. org/10.21273/JASHS.125.5.588

Rajkai K., Végh K.R., and Nacsa T., 2005. Electrical capacitance of roots in relation to plant electrodes, measuring frequency and root media. Acta Agronomica Hungarica, 53, 197-210, https://doi.org/10.1556/AAgr.53.2005.2.8

Repo T., Korhonen A., Lehto T., and Silvennoinen R., 2016. Assessment of frost damage in mycorrhizal and non-mycorrhizal roots of Scots pine seedlings using classification analysis of their electrical impedance spectra. Trees, 30, 483-495, https://doi.org/10.1007/s00468-015-1171-x.

Repo T., Laukkanen J., and Silvennoinen R., 2005. Measurement of the tree root growth using electrical impedance spectroscopy. Silva Fennica, 39, 159-166, https://doi. org/10.14214/sf.380

Richards R.A., 1991. Crop improvement for temperate Australia: Future opportunities. Field Crops Res., 26, 141-169, https:// doi.org/10.1016/0378-4290(91)90033-R.

Richards R.A. and Passioura J.B., 1989. A breeding program to 
reduce the diameter of the major xylem vessel in the seminal roots of wheat and its effect on grain yield in rain-fed environments. Australian J. Agric. Res., 40, 943-950, https://doi.org/10.1071/AR9890943.

Richards R.A., Rebetzke G.J., Watt M., Condon A.G., Spielmeyer W., and Dolferus R., 2010. Breeding for improved water productivity in temperate cereals: phenotyping, quantitative trait loci, markers and the selection environment. Funct. Plant Biol., 37, 85-97, https://doi. org/10.1071/FP09219.

Robinson H., Kelly A., Fox G., Franckowiak J., Borrell A., and Hickey L., 2018. Root architectural traits and yield: exploring the relationship in barley breeding trials. Euphytica, 214, 151, https://doi.org/10.1007/s10681-018-2219-y.

Sabo D., McMurray G., and Rains G., 2016. Presymptomatic disease detection and nanoparticle-enhanced electrical capacitance tomography. IFAC-PapersOnLine, 49, 116120, https://doi.org/10.1016/j.ifacol.2016.10.022.

Sharma S. and Carena M.J., 2016. BRACE: A Method for high throughput maize phenotyping of root traits for short-season drought tolerance. Crop Science, 56, 2996-3004, https://doi.org/10.2135/cropsci2016.02.0116.

Smit A.L., Bengough A.G., Engels C., Noordwijk M., Pellerin S., and Geijn S.C., 2000. Root Methods. A Handbook. Springer-Verlag, Berlin Heidelberg, Germany, https://doi. org/10.1007/978-3-662-04188-8.

Středa T., Dostál V., Horáková V., and Chloupek O., 2012. Effective use of water by wheat varieties with different root system sizes in rain-fed experiments in Central Europe. Agric. Water Manag., 104, 203-209, https://doi. org/10.1016/j.agwat.2011.12.018.

Středa T. and Chloupek O., 2013. Kit for measuring size of root system. Patent Number: CZ201100530-A3. Derwent Primary Accession Number: 2013-D47711.

Svačina P., Středa T., and Chloupek O., 2014. Uncommon selection by root system size increases barley yield. Agron. Sustain. Dev., 34, 545-551, https://doi.org/10.1007/ s13593-013-0160-y.

Školníková M. and Škarpa P., 2016. The influence of deficient nutrition on growth and root activity of maize (Zea mays L.) under hydroponic conditions. In: MendelNet 2016: Proc. Int. Ph.D. Students Conference. Mendel University in Brno, Czech Republic, 140-145.

Šmardová M., Klimešová J., and Stř̌eda T., 2018. Improved root system for better wheat drought tolerance. In: MendelNet 2018: Proc. Int. Ph.D. Students Conf., Mendel University in Brno, Czech Republic, 90-94.

Takács T., Füzy A., Rajkai K., and Cseresnyés I., 2014. Investigation of arbuscular mycorrhizal status and functionality by electrical impedance and capacitance measurement: New method for description of AMF functionality. Acta Biologica Szegediensis, 58, 55-59.

Tron S., Bodner G., Laio F., Ridolfi L., and Leitner D., 2015. Can diversity in root architecture explain plant water use efficiency? A modeling study. Ecol. Model., 312, 200-210, https://doi.org/10.1016/j.ecolmodel.2015.05.028.

Tsukahara K., Yamane K., Yamaki Y., and Honjo H., 2009. A nondestructive method for estimating the root mass of young peach trees after root pruning using electrical capacitance measurements. J. Agric. Meteorology, 65, 209-213, https://doi.org/10.2480/agrmet.65.2.6.

Vamerali T., Bandiera M., Coletto L., Zanetti F., Dickinson N.M., and Mosca G., 2009. Phytoremediation trials on metal- and arsenic-contaminated pyrite wastes (Torviscosa, Italy). Environ. Pollution, 157, 887-894, https://doi. org/10.1016/j.envpol.2008.11.003.

Vamerali T., Saccomani M., Bona S., Mosca G., Guarise M., and Ganis A., 2003. A comparison of root characteristics in relation to nutrient and water stress in two maize hybrids. Plant Soil, 255, 157-176, https://doi.org/10.1023/ A:1026123129575.

van Beem J., Smith M.E., and Zobel R.W., 1998. Estimating root mass in maize using a portable capacitance meter. Agron. J., 90, 566-570, https://doi.org/10.2134/agronj1998. 00021962009000040021x.

Vintrlíková E., Klimešová J., and Středa T., 2015. Possibility of selection for higher seed vigour of barley. In MendelNet 2015: Proc. Int. Ph.D. Students Conf., November 11, Mendel University in Brno, Czech Republic, 99-102.

Waines J.G. and Ehdaie B., 2007. Domestication and crop physiology: roots of green-revolution wheat. Ann. Bot., 100, 991-998, https://doi.org/10.1093/aob/mcm180.

Waisel Y., Eshel A., Beeckman T., and Kafkafi U., 1991. Plant roots: the hidden half. Marcel Dekker Inc., New-York, USA.

Wang Ch., Liu W., Li Q., Ma D., Lu H., Feng W., Xie Y., Zhu Y., and Guo T., 2014. Effects of different irrigation and nitrogen regimes on root growth and its correlation with above-ground plant parts in high-yielding wheat under field conditions. Field Crops Res., 16, 138-149, https://doi. org/10.1016/j.fcr.2014.04.011.

Wendling M., Büchi L., Amossé C., Sinaj S., Walter A., and Charles R., 2016. Influence of root and leaf traits on the uptake of nutrients in cover crops. Plant Soil, 409, 419-434, https://doi.org/10.1007/s11104-016-2974-2.

Worku M., Bänziger M., Schulte Auf'm Erley G., Friesen D., Diallo A.O., and Horst W.J., 2012. Nitrogen efficiency as related to dry matter partitioning and root system size in tropical mid-altitude maize hybrids under different levels of nitrogen stress. Field Crops Res., 130, 57-67, https://doi. org/10.1016/j.fcr.2012.02.015.

Wu W., Duncan R.W., and Ma B., 2017. Quantification of canola root morphological traits under heat and drought stresses with electrical measurements. Plant Soil, 415, 229-244, https://doi.org/10.1007/s11104-016-3155-z.

Wu W. and Ma B.-L., 2016. A new method for assessing plant lodging and the impact of management options on lodging in canola crop production. Sci. Rep., 6, 31890, https://doi. org/10.1038/srep31890. 